\title{
Farklı ticari yıkama çözeltilerinin kiraz mikrobiyal kalitesi üzerine etkisi
}

\author{
Burcu Kaya $^{\mathrm{a} 1 *}$, Aycan Cinar ${ }^{\mathrm{b} 2}$, Ferda Sobac1 ${ }^{\mathrm{c} 3}$ \\ ${ }^{a}$ Çanakkale Onsekiz Mart Üniversitesi, Mühendislik Fakültesi, Gıda Mühendisliği Bölümü, Çanakkale, Türkiye \\ b Bursa Teknik Üniversitesi, Mühendislik ve Doğa Bilimleri Fakültesi, Gıda Mühendisliği Bölümü, Bursa, Türkiye \\ ${ }^{\mathrm{c}}$ Perla Fruit Gıda Sanayi ve Ticaret Anonim Sirketi, Bursa, Türkiye
}

İstanbul Sabahattin Zaim Üniversitesi Fen Bilimleri Enstitüsü Dergisi (2021) 3 (3): 184-188

https://doi.org/10.47769/izufbed.958125

(iD) $O R C I D{ }^{1} 0000-0003-1755-7705 ;{ }^{2} 0000-0003-2038-725 \mathrm{X} ;{ }^{3} 0000-0003-1766-8667$

\begin{tabular}{l}
\hline YAYIN BİLGİSİ \\
\hline Yayın geçmişi: \\
Gönderilen tarih: 28 Haziran 2021 \\
Kabul tarihi: 23 Eylül 2021 \\
\hline Anahtar kelimeler: \\
Kiraz \\
Semperfresh ${ }^{\mathrm{TM}}$ \\
Bioflux \\
Huwa-san \\
Flavonin ${ }^{\circledR}$ food
\end{tabular}

\begin{tabular}{l}
\hline ÖZET \\
\hline Taze tüketime sunulan kiraz, klimakterik olmayan meyve grubunda yer almaktadır. Bundan dolayı hasat sonrası \\
uygulanacak muhafaza yöntemleri kirazın raf ömrü için oldukça önemlidir. Bu çalışmada soğuk depolarda muhafaza \\
edilerek tüketime sunulan kirazların muhafaza süresi boyunca mikrobiyal kalitesinin arttırılması amaçlanmıştır. \\
Çalışmada Konya Hadim bölgesinden Temmuz 2020 tarihinde hasat edilen Ziraat 0900 çeşidi kiraz örnekleri \\
kullanılmıştır. \%2.5 Semperfresh ${ }^{\mathrm{TM}}, \% 2$ Bioflux ve $\% 3$ Bioflux püskürtme, $\% 1.5$ Huwa-San ve $\% 1$ Flavonin ${ }^{\circledR}$ Food \\
daldırma yöntemleriyle kiraz örneklerine uygulanmıştır. Yıkama çözeltileri uygulanan kiraz örnekleri 15 gün $4^{\circ} \mathrm{C}$ 'de \\
muhafaza edilmiştir. Muhafaza süresi boyunca belirli periyotlarda toplam aerobik mezofilik bakteri sayımı, toplam \\
psikrofil bakteri sayımı, maya-küf sayımı analizleri yapılmıştır. Sonuç olarak kontrol örneği ile karşışışırıllığında \\
toplam aerobik mezofilik bakteri sayısı için \%2 Bioflux ve \%1.5 Huwa-San çözeltilerinin yaklaşık 2.5 log KOB/g; \\
toplam psikrofil bakteri sayısı ve maya-küf sayısı için \%1.5 Huwa-San çözeltisinin yaklaşık 2 log KOB/g düzeyinde \\
önemli azalma sağladığı belirlenmiştir $(P<0.05)$.
\end{tabular}

\section{The effect of different commercial washing solutions on sweet cherry microbial quality}

\begin{tabular}{l}
\hline ARTICLE INFO \\
\hline Article history: \\
Received: 28 June 2021 \\
Accepted: 23 September 2021 \\
\hline Key words: \\
Sweet cherry \\
Semperfresh ${ }^{\mathrm{TM}}$ \\
Bioflux \\
Huwa-san \\
Flavonin ${ }^{\circledR}$ food
\end{tabular}

\begin{abstract}
Sweet cherry offered for fresh consumption is included in the non-climacteric fruit group. Therefore, preservation methods to be applied after harvesting are important for the shelf life of sweet cherries. In this study, it is aimed to increase the microbial quality of sweet cherries that are preserved in cold storages and offered for consumption during the storage period. Samples of Ziraat 0900 variety harvested in Konya Hadim region in July 2020 were used in the study. 2.5\% Semperfresh ${ }^{\mathrm{TM}}, 2 \%$ Bioflux and 3\% Bioflux with spraying method and $1.5 \%$ Huwa-San and $1 \%$ Flavonoid ${ }^{\circledR}$ Food with dipping method were applied to samples. Samples to which washing solutions were applied were stored for 15 days $\left(4^{\circ} \mathrm{C}\right)$. During the storage period, analyzes of total mesophilic aerobic bacteria count, total psychrophile bacteria count, yeast-mold counts were performed at certain periods. As a result, approximately $2.5 \log$ CFU/g of $2 \%$ Bioflux and 1.5\% Huwa-San solutions for the total mesophilic aerobe bacteria count; it was determined that $1.5 \%$ Huwa-San solution provided a significant decrease of approximately $2 \mathrm{log} \mathrm{CFU} / \mathrm{g}$ level for total psychrophile bacteria, yeast and molds $(P<0.05)$.
\end{abstract}

\section{Giriş}

Dünyada yaklaşık 1500 çeşidi olan kiraz, sert çekirdekli, sulu, tatlı aromalı bir meyvedir (İncekara ve Selek, 2020). Gıda ve Tarım Örgütü (FAO) 2017 verilerine göre, Türkiye, dünya kiraz üretiminin büyük payına sahip beş ülke arasında yer almaktadır. Ayrıca bu verilere göre son beş yıl içerisinde kiraz üretiminde en yükssek artışın Türkiye'de olduğu bildirilmiştir (Çelik ve Sarıaltın, 2019). TÜİK tarafindan yayımlanan son rapora göre ise 2020 yılında, bir önceki yıla göre \%9.1 artış olduğu bildirilmiştir (TÜİK, 2020).
Ülkemizdeki kiraz yetiştiriciliğinde 0900 Ziraat önemli bir kiraz çeşidi olarak bilinmektedir (Onursal vd., 2013). İri, sert, tatll, çatlamaya dayanıklı meyvesi, uzun-yeşil sapı ve muhafazaya dayanıklılığ 1 ile Türkiye'den ihraç edilen kiraz çeşitlerinin en önemli payını oluşturmaktadır.

Kiraz klimakterik özelliğe sahip olmayan bir meyvedir. Bundan dolayı hasat sonrasında kolaylıkla sap kararmaları ve çürümeleri, meyvede sertlik ve renk kaybı gibi istenmeyen durumlar meydana gelebilmektedir (Torçuk vd., 2016). Bu tür istenmeyen durumların temel kaynağı hasat sonrasında kiraz meyvesinde meydana gelen 
küf-maya (Penicillium, Botrytis ve Monilia) gelişimidir (Serrano vd., 2005). Küf-maya gelişimi kiraz meyvesinin raf ömrünün kısalmasına ve ekonomik kayıplara neden olmaktadır (Marquenie vd., 2002). Birçok üretici küf-maya gelişimini engellemek amacıyla kimyasal fungusitleri kullanmaktadır (Martínez-Romero vd., 2006; Conte vd., 2009). Ancak kimyasal fungusitler ürün yüzeyinde kalıntı bırakarak tüketiciyi olumsuz etkilemektedir. Bu nedenle, güvenli ve çevre dostu yeni koruma teknolojilerine ihtiyaç vardır. Bu amaçla birçok çalışmada soğuk muhafaza, kontrollü atmosfer paketleme, modifiye atmosfer paketleme ve yenilebilir film ile kaplama teknolojileri önerilmiştir (Tokatlı ve Demirdöven, 2020).

Hasat edilen kiraz meyvesi işletmeye ulaştığında meyve solunumunun yavaşlatılması ve mikrobiyal yükün azaltılması amacıyla su ile duşlama yapılarak, hızlı bir şekilde $2-4^{\circ} \mathrm{C}$ 'ye kadar soğutulmaktadır. $\mathrm{Bu}$ işlem gerçekleştirilirken aynı zamanda meyvelerin yıkanması da sağlanmaktadır. Ürünlerin etkin bir yıkama ile mikrobiyal yükünün azaltılması raf ömrünü uzatmada temel etken olduğu bilinmektedir. Son yıllarda sektörde yıkamanın etkinliğinin artırılmasında; antimikrobiyal madde içeren ticari biyosidal ürünler ile yıkama yapıldığg bilinmektedir.

Semperfresh ${ }^{\mathrm{TM}}$, Bioflux, Huwa-San ve Flavonin ${ }^{\circledR}$ Food gibi çözeltiler gıda sektöründe kullanılan ticari biyosidal ürünler arasında yer almaktadır. Semperfresh ${ }^{\mathrm{TM}}$ sodyum çözeltisi, karboksimetilselüloz ve yă asitlerinin mono-digliseridleri ve sukroz esterlerini içeren bir karışım olup, taze tüketime sunulan meyveler için kaplama çözeltisi olarak kullanılmaktadır (Park ve Zhao, 2006). Bioflux çözeltisi, bitki esansiyel yağı ve mikrobiyal peptit içeren doğal bir üründür (Nanomik Biotechnology, 2021). Flavonin ${ }^{\circledR}$ Food emülgatör ve bitki esansiyel yağlarını içeren diğer bir doğal ürün olup, bakteri gelişiminin kontrolü ve çürümeyi önlemesi nedeniyle önerilmektedir (CNS, 2021). Huwa-San çözeltisi, gümüş ile stabilize edilmiş hidrojen peroksit formülasyonundan oluşmaktadır (Al-Azzazy ve Alhewairini, 2018). Huwa-San çözeltisi insanlar için toksik olmaması, tatsız ve kokusuz olmasından dolayı patojen bakteriler ve küfler ile mücadelede önerilmektedir (Ha vd., 2011; Türküsay ve Tosun, 2005).

Bu çalışmada, pratikte kullanılan önemli ticari yıkama çözeltilerinin, kiraz meyvesinin mikrobiyal kalitesi üzerine etkisi araştırılmıştır. Conte vd. (2009) tarafindan yapılan çalı̧̧mada kiraz meyvesinin mikrobiyal floranın belirlenmesinde maya-küf sayımı, toplam aerobik mezofilik bakteri sayısı ve toplam psikrofil bakteri sayısı ile benzerlik gösterdiği bildirilmiştir. Bundan dolayı yaptığımız çalışmada çeşitli yıkama işlemi uygulanan kiraz örneklerinin mikrobiyal kalitesi, maya-küf sayımı, toplam aerobik mezofilik bakteri ve toplam psikrofil bakteri sayımı analizi ile takip edilmiştir.

\section{Materyal ve Yöntem}

\subsection{Kiraz örnekleri}

Çalışmada Konya Hadim bölgesinden Temmuz 2020 tarihinde hasat edilen Ziraat 0900 çeşidi kiraz kullanılmıştır. Kiraz örnekleri Perla Fruit Gıda San. Tic. A.Ş aracılığ 1 ile temin edilmiştir. Hasat edilen meyveler sağlam, sapsız, çökük, çatlak ve olgun olma durumuna göre gruplara ayrılmıştır. Ardından analize alınacak örneklerden, her bir grubu içerecek şekilde $500 \mathrm{~g}$ meyve karışımı hazırlanmıştır. Böylece kirazları ambalajlamadan önce yapılan ayıklama işlemi sırasında oluşabilecek durum simüle edilmiştir.
2.2 Yıkama çözeltilerinin kiraz örneklerine uygulanması ve depolama

Y1kama çözeltisi olarak Semperfresh ${ }^{\mathrm{TM}}$ (Xeda International, ABD), Bioflux (Nanomik Biyoteknoloji, Türkiye), Huwa-San (Roam Technology, B-Houthalen, Belçika) ve Flavonin ${ }^{\circledR}$ Food (CNS, Avusturya) kullanılmıştır. Yıkama çözeltileri Çizelge 1'de belirtildiği şekilde kiraz örneklerine uygulanmıştır. Kontrol grubu olarak suya daldırılarak yıkanan kiraz örnekleri kullanılmıştır. Tabanında absorbe ped bulunan kapaklı polietilen ambalajlara yerleştirilen örnekler, Lifespan (Amcor Flexibles, Victoria, Avusturalya) tipi torbalarda 15 gün boyunca $+4{ }^{\circ} \mathrm{C}$ 'de muhafaza edilmiştir.

Çizelge 1. Yıkama çözeltilerinin konsantrasyonu ve uygulama yöntemi

\begin{tabular}{lcc}
\hline $\begin{array}{l}\text { Y1kama çözeltilerinin } \\
\text { ticari adı }\end{array}$ & $\begin{array}{c}\text { Konsantrasyon } \\
(\% \mathrm{v} / \mathrm{v})\end{array}$ & $\begin{array}{c}\text { Uygulama } \\
\text { yöntemi }\end{array}$ \\
\hline Semperfresh $^{\mathrm{TM}}$ & 2.5 & 5 kez püskürtme \\
Bioflux & 2 ve 3 & 5 kez püskürtme \\
Huwa-San & 1.5 & 2 dakika daldırma \\
Flavonin ${ }^{\circledR}$ Food & 1 & 2 dakika daldırma \\
\hline
\end{tabular}

2.3 Örneklerin analize hazırlanması ve mikrobiyal yükün belirlenmesi

Hasat gününden itibaren örneklere 15 gün boyunca periyodik ( 0 . gün, 3. gün, 5.gün, 7. gün ve 15. gün) olarak toplam aerobik mezofilik bakteri sayımı, toplam psikrofil bakteri sayımı ve mayaküf sayımı yapılarak, kiraz örnekleri fotoğraflanmıştır.

Analizlere başlamadan önce ambalajın kapağı açılmadan birkaç kez sallanarak, örnekleme homojenliği sağlanmıştır. Steril koşullar altında $10 \mathrm{~g}$ meyve örneği tartılarak, $90 \mathrm{~mL}$ fizyolojik tuzlu su (\%0.85) içerisinde stomacher kullanılarak 1 dakika homojenize edilmiştir. Tüm analizler uygun dilüsyon serileri oluşturulduktan sonra gerçekleştirilmiştir (Kaya ve Demirel Zorba, 2018).

Toplam aerobik mezofilik bakteri (TAMB) sayımı, Plate Count Agar (Oxoid, İngiltere) besiyerine hazırlanan dilüsyonlardan yayma plak yöntemi ile ekim yapılarak gerçekleştirilmiştir. Petrilerin $30 \pm 2^{\circ} \mathrm{C}$ ' de 48 saat inkübasyonu sonunda TAMB sayısı belirlenmiştir (Serradila vd., 2010). Toplam psikrofil bakteri sayımı, Plate Count Agar besiyerine hazırlanan dilüsyonlardan dökme plak yöntemi ile ekim yapılarak gerçekleştirilmiştir. Ekim sonunda petriler, $7 \pm 2^{\circ} \mathrm{C}$ 'de 10 gün inkübasyona bırakılarak Toplam psikrofil bakteri sayıs1 tespit edilmiştir (Conte vd., 2009). Maya-küf sayısının belirlenmesi; uygun seyreltmelerden Potato Dextrose Agar (Oxoid, İngiltere) besiyerine yayma plak yöntemi kullanılarak gerçekleştirilmiştir. Daha sonra $25 \pm 2^{\circ} \mathrm{C}$ 'de 3 gün süre ile inkübasyona bırakılmıştır (Tokatlı ve Demirdöven, 2020). Tüm sayım sonuçları koloni oluşturan birim/gram $(\mathrm{KOB} / \mathrm{g})$ olarak verilmiştir.

\section{4 İstatistiksel analiz}

İstatistiksel değerlendirmeler SPSS 23.0 (SPSS Inc., Chiago, IL, USA) programı kullanılarak yapılmıştır. İstatistiksel farklılıklar tek yönlü ANOVA ile belirlenerek karşılaştırmalar Duncan çoklu karşılaştırma testi uygulanarak yapılmıştır. Ayrıca $P<0.05$ istatistiksel açıdan anlamlı kabul edilmiş ve sonuçlar ortalama \pm standart sapma şeklinde verilmiştir. 


\section{Bulgular ve Tartışma}

Tüm örnek yüzeylerinde 3. günden itibaren terleme başlamıştır (Şekil 1). Buna ek olarak \%2.5 Semperfresh ${ }^{\mathrm{TM}}$ uygulanan kiraz örnekleri dışındaki tüm örneklerde, renkte matlaşma olduğu gözlemlenmiştir. Depolamanın 15. günde hem kontrol örneğinde hem de $\% 1$ Flavonin ${ }^{\circledR}$ Food uygulanan kiraz örneklerinde görünür küf lezyonları tespit edilmiştir. Toplam aerobik mezofilik bakteri sayısı, tüm örnek gruplarında depolama süresine bağlı olarak artış göstermiştir (Çizelge 2). 0. gün sayımlarına göre başlangıç TAMB sayıs1, en yüksek kontrol örneğinde, $\% 2.5$ Semperfresh $^{\mathrm{TM}}$ ve $\% 2$ Bioflux çözeltileri ile yıkanan kiraz örneklerinde belirlenmiştir. $\% 1.5$ Huwa-San ve \%1 Flavonin ${ }^{\circledR}$ Food uygulanan kiraz örneklerinde ise TAMB saptanmamıştır. 15. gün sonunda ise en yüksek mikrobiyal yük, kontrol örneğinde ve \%3 Bioflux uygulanan kiraz örneklerinde tespit edilirken, en düşük mikrobiyal yük $\% 2$ Bioflux ve \%1.5 Huwa-San uygulanan örneklerde tespit edilmiştir. Kontrol örneği ile kıyaslandığında, \%3 Bioflux çözeltisi uygulanan örnek dışındaki tüm örneklerin, TAMB sayısında istatistiksel açıdan önemli bir azalma olmadığı belirlenmiştir $(P<0.05)$. Ancak en yüksek azalmanın (yaklaşık $2.5 \log \mathrm{KOB} / \mathrm{g}$ ) \%2 Bioflux ve \%1.5 Huwa-San uygulanan örneklerde olduğu saptanmıştır.
Toplam psikrofil bakteri sayısı, tüm örnek gruplarında depolama süresine bağlı olarak artış göstermiştir (Çizelge 3). En yüksek başlangıç yükü \%3 Bioflux uygulanan örneklerde tespit edilirken, en düşük başlangıç yükü \%1.5 Huwa-San uygulanan örneklerde tespit edilmiştir. 15 gün depolama sonunda $\% 2.5$ Semperfresh $^{\mathrm{TM}}$ ve $\% 3$ Bioflux uygulanan örneklerde kontrole göre azalma olmadığ 1 gözlenmiştir. Ancak kontrol ile karşılaştırıldığında \%2 Bioflux, $\% 1.5$ Huwa-San ve \%1 Flavonin ${ }^{\circledR}$ Food uygunan örneklerde istatistiksel açıdan önemli azalma olduğu belirlenmiştir $(P<0.05)$. En yüksek azalma $(2 \log \mathrm{KOB} / \mathrm{g}) \% 1.5$ Huwa-San uygulanan örneklerde saptanmıştır.

Kontrol, Semperfresh ${ }^{\mathrm{TM}}$ ve Bioflux örneklerinde 0. ve 3. günde maya-küf tespit edilirken, \%1.5 Huwa-San ve \%1 Flavonin ${ }^{\circledR}$ Food uygulanan örneklerin 0 . ve 3. gün analizlerinde maya-küf tespit edilmemiştir. Ancak maya ve küf sayısı, tüm örnek gruplarında depolama süresine bağlı olarak artış göstermiştir (Çizelge 4). Ayrıca 15 gün depolama sonunda kontrol örneği ile kıyaslandığında $\% 1.5$ Huwa-San uygulanan örneklerde önemli bir azalma (yaklaşık 2 log $\mathrm{KOB} / \mathrm{g}$ ) olduğu belirlenmiştir. Buna karşın \%1 Flavonin ${ }^{\circledR}$ Food uygulanan örneklerin mikrobiyal yükünün en yüksek değere sahip olduğu saptanmıştır.

Çizelge 2. Depolama boyunca farklı yıkama çözeltileri uygulanan kiraz örneklerinde TAMB sayısı $(\log$ KOB/g)

\begin{tabular}{|c|c|c|c|c|c|}
\hline \multirow{2}{*}{ Numune Ad 1} & \multicolumn{4}{|c|}{ Depolama Süresi } & \multirow[b]{2}{*}{ 15.gün } \\
\hline & 0 . gün & 3. gün & 5. gün & 7. gün & \\
\hline Kontrol & $2.81 \pm 0.04^{\mathrm{Ac}}$ & $1.65 \pm 0.06^{\mathrm{Be}}$ & $3.63 \pm 0.03^{\mathrm{Ab}}$ & $2.30 \pm 0.00^{\mathrm{BCd}}$ & $5.03 \pm 0.04^{\mathrm{Aa}}$ \\
\hline$\% 2.5$ Semperfresh $^{\mathrm{TM}}$ & $2.00 \pm 0.00^{\mathrm{Ad}}$ & $2.74 \pm 0.01^{\mathrm{Ab}}$ & $2.00 \pm 0.00^{\mathrm{Cd}}$ & $2.45 \pm 0.21^{\mathrm{Bc}}$ & $4.85 \pm 0.10^{\mathrm{Ca}}$ \\
\hline$\% 2$ Bioflux & $2.69 \pm 0.00^{\mathrm{Aa}}$ & $2.40 \pm 0.11^{\mathrm{Ab}}$ & $2.00 \pm 0.00^{\mathrm{Cc}}$ & $2.00 \pm 0.00^{\mathrm{Cc}}$ & $2.70 \pm 0.11^{\mathrm{Da}}$ \\
\hline$\% 3$ Bioflux & $1.88 \pm 0.15^{\mathrm{Bb}}$ & $1.87 \pm 0.04^{\mathrm{Cb}}$ & $0.00 \pm 0.00^{\mathrm{Dd}}$ & $2.05 \pm 0.08^{\mathrm{Cb}}$ & $5.08 \pm 0.01^{\mathrm{ABa}}$ \\
\hline$\% 1.5$ Huwa-San & $<10^{\mathrm{Cc}}$ & $1.53 \pm 0.08^{\mathrm{Bb}}$ & $1.53 \pm 0.08^{\mathrm{Eb}}$ & $1.58 \pm 0.15^{\mathrm{Db}}$ & $2.57 \pm 0.04^{\mathrm{Da}}$ \\
\hline$\% 1$ Flavonin ${ }^{\circledR}$ Food & $<10^{\mathrm{Cd}}$ & $1.96 \pm 0.16^{\mathrm{Bc}}$ & $2.15 \pm 0.21 \mathrm{~B}^{\mathrm{Cc}}$ & $3.09 \pm 0.19^{\mathrm{Ab}}$ & $4.91 \pm 0.04^{\mathrm{BCa}}$ \\
\hline
\end{tabular}

*Aynı sütun üzerinde belirtilen farklı büyük harfler yıkama çözeltileri arasındaki istatistiksel açıdan ortalamalar arasındaki farklılı̆̆ ifade etmektedir $(P<0.05)$.

*Aynı satır üzerinde belirtilen farklı küçük harfler günler arasındaki istatistiksel açıdan ortalamalar arasındaki farklılı̆̆ı ifade etmektedir $(P<0.05)$.

Çizelge 3. Depolama boyunca farklı yıkama çözeltileri uygulanan kiraz örneklerinde toplam psikrofil bakteri sayısı (log KOB/g)

\begin{tabular}{|c|c|c|c|c|c|}
\hline \multirow{2}{*}{ Numune Ad 1} & \multicolumn{4}{|c|}{ Depolama Süresi } & \multirow[b]{2}{*}{ 15.gün } \\
\hline & 0 . gün & 3. gün & 5. gün & 7. gün & \\
\hline Kontrol & $3.14 \pm 0.04^{\mathrm{Ac}}$ & $2.84 \pm 0.21^{\mathrm{BCd}}$ & $3.83 \pm 0.02^{\mathrm{Ab}}$ & $3.76 \pm 0.07^{\mathrm{Bb}}$ & $5.15 \pm 0.03^{\mathrm{Ba}}$ \\
\hline$\% 2.5$ Semperfresh $^{\mathrm{TM}}$ & $2.72 \pm 0.05^{\mathrm{Be}}$ & $3.07 \pm 0.05^{\mathrm{BCd}}$ & $3.47 \pm 0.04^{\mathrm{BCc}}$ & $4.26 \pm 0.01^{\mathrm{Ab}}$ & $5.35 \pm 0.01^{\mathrm{Aa}}$ \\
\hline$\% 2$ Bioflux & $1.58 \pm 0.15^{\mathrm{Ce}}$ & $3.07 \pm 0.05^{\mathrm{BCd}}$ & $3.48 \pm 0.03^{\mathrm{BCc}}$ & $4.20 \pm 0.03^{\mathrm{Ab}}$ & $5.04 \pm 0.01^{\mathrm{Ca}}$ \\
\hline$\% 3$ Bioflux & $3.23 \pm 0.00^{\mathrm{Ad}}$ & $3.77 \pm 0.00^{\mathrm{Ab}}$ & $3.54 \pm 0.03^{\mathrm{Bc}}$ & $3.64 \pm 0.13^{\mathrm{Bbc}}$ & $5.29 \pm 0.02^{\mathrm{Aa}}$ \\
\hline$\% 1.5$ Huwa-San & $0.69 \pm 0.00^{\mathrm{Dd}}$ & $1.00 \pm 0.00^{\mathrm{Dc}}$ & $1.97 \pm 0.03^{\mathrm{Db}}$ & $2.15 \pm 0.21^{\mathrm{Cb}}$ & $3.10 \pm 0.09^{\mathrm{Ea}}$ \\
\hline$\% 1$ Flavonin ${ }^{\circledR}$ Food & $2.69 \pm 0.11^{\mathrm{Bd}}$ & $3.15 \pm 0.21^{\mathrm{Bc}}$ & $3.40 \pm 0.01^{\mathrm{Cc}}$ & $4.37 \pm 0.01^{\mathrm{Aa}}$ & $4.06 \pm 0.01^{\mathrm{Db}}$ \\
\hline
\end{tabular}

*Aynı sütun üzerinde belirtilen farklı büyük harfler yıkama çözeltileri arasındaki istatistiksel açıdan ortalamalar arasındaki farklılığı ifade etmektedir $(P<0.05)$.

* Aynı satır üzerinde belirtilen farklı küçük harfler günler arasındaki istatistiksel açıdan ortalamalar arasındaki farklılı̆̆ ifade etmektedir $(P<0.05)$.

Çizelge 4. Depolama boyunca farklı yıkama çözeltileri uygulanan kiraz örneklerinde maya-küf sayısı $(\log \mathrm{KOB} / \mathrm{g})$

\begin{tabular}{lccccc}
\hline \multirow{2}{*}{ Numune Ad1 } & \multicolumn{5}{c}{ Depolama Süresi } \\
\cline { 2 - 6 } & 0. gün & 3. gün & 5. gün & 7. gün & 15.gün \\
\hline Kontrol & $1.96 \pm 0.16^{\mathrm{Bd}}$ & $2.88 \pm 0.01^{\mathrm{Ac}}$ & $3.25 \pm 0.03^{\mathrm{ABb}}$ & $3.15 \pm 0.21^{\mathrm{Bbc}}$ & $4.90 \pm 0.03^{\mathrm{Ca}}$ \\
\%2.5 Semperfresh & $2.00 \pm 0.00^{\mathrm{Bc}}$ & $2.92 \pm 0.03^{\mathrm{Ab}}$ & $2.15 \pm 0.21^{\mathrm{Dc}}$ & $2.80 \pm 0.14^{\mathrm{Cb}}$ & $4.66 \pm 0.04^{\mathrm{CDa}}$ \\
\%2 Bioflux & $2.62 \pm 0.21^{\mathrm{Ab}}$ & $2.62 \pm 0.21^{\mathrm{Bb}}$ & $2.75 \pm 0.21^{\mathrm{Cb}}$ & $3.43 \pm 0.21^{\mathrm{ACa}}$ & $3.68 \pm 0.26^{\mathrm{Ea}}$ \\
$\% 3$ Bioflux & $2.45 \pm 0.21^{\mathrm{Ac}}$ & $2.65 \pm 0.06^{\mathrm{Bc}}$ & $2.82 \pm 0.31^{\mathrm{BCc}}$ & $3.72 \pm 0.06^{\mathrm{Ab}}$ & $5.39 \pm 0.02^{\mathrm{Ba}}$ \\
$\%$ 1.5 Huwa-San & $<10^{\mathrm{Cc}}$ & $<10^{\mathrm{Cc}}$ & $2.15 \pm 0.21^{\mathrm{Db}}$ & $2.15 \pm 0.21^{\mathrm{Db}}$ & $2.71 \pm 0.17^{\mathrm{Fa}}$ \\
\%1 Flavonin ${ }^{\circledR}$ Food & $<10^{\mathrm{Cc}}$ & $<10^{\mathrm{Cc}}$ & $2.15 \pm 0.21^{\mathrm{Db}}$ & $3.73 \pm 0.07^{\mathrm{Ab}}$ & $5.47 \pm 0.00^{\mathrm{Aa}}$ \\
\hline
\end{tabular}

*Aynı sütun üzerinde belirtilen farklı büyük harfler yıkama çözeltileri arasındaki istatistiksel açıdan ortalamalar arasındaki farklılı̆̆ ifade etmektedir $(P<0.05)$.

*Aynı satır üzerinde belirtilen farklı küçük harfler günler arasındaki istatistiksel açıdan ortalamalar arasındaki farklılı̆̆ı ifade etmektedir $(P<0.05)$. 
Yapılan çalışmalar sonucunda, kiraz raf ömrünün uzatılmasına yönelik olarak; yüksek hidrostatik başınç, ultrases, UV radyasyon, elektrolize su, modifiye atmosfer, kontrollü atmosfer ve yenilebilir film ile kaplama gibi birçok yöntem önerilmektedir (Marquenie vd., 2002; Koyuncu vd., 2008; Sharma vd., 2010; Petriccione vd., 2014; Muzaffar vd., 2016; Hayta ve Aday, 2015; Giménez vd., 2016; Del Árbol vd., 2016; Abdipour vd., 2020). Ancak önerilen yöntemlerin birçoğu yüksek maliyeti nedeniyle laboratuvar düzeyinden ileriye gidememiştir. Ülkemizdeki işletmelerin çoğunlukla soğuk muhafaza ve MAP uygulamalarını tercih ettiği bilinmektedir (Conte vd., 2009). Ancak her iki uygulamanın da kiraz raf ömrünü uzatmada önemli bir katkısı olmadığı saha uygulamalarında görülmektedir. Ayrıca Conte vd. (2009), MAP ve atmosferik koşulların kiraz örneklerinin kalitesine benzer etki gösterdiğini ve MAP ile farklı muhafaza yöntemlerinin kombine kullanılması gerektirdiğini bildirmiştir. Benzer şekilde Şen vd. (2016) tarafindan yapılan başka bir çalışmada, farklı MAP torbalarında muhafaza edilen kiraz meyvelerinde 14 gün depolama sonrasında çürüklük oluştuğu ifade edilmiştir. Yaptığımız çalışmada da benzer şekilde kontrol grubunun depolanma süresinin 15. günde küf lezyonları tespit edilmiştir.
Çalışmada elde edilen sonuçlara göre kullanılan çözeltilerin, özellikle de \%2 Bioflux, \%1.5 Huwa-San ve \%1 Flavonin ${ }^{\circledR}$ Food çözeltileri, kiraz örneklerinin mikrobiyal yükünü önemli düzeyde azalttığ 1 ve en etkili uygulamanın ise \%1.5 Huwa-San uygulaması olduğunu göstermiştir. Ayrıca \%2.5 Semperfresh ${ }^{\mathrm{TM}}$ çözeltisinin mikrobiyal yük açısından kontrol ile paralel ilerlediği belirlenmiştir. Yaman ve Bayındırl (2002), kiraz meyvelerine \%2.5 Semperfresh $^{\mathrm{TM}}$ kaplama uygulamasının maya-küf sayısında kontrole göre önemli düzeyde olmayan artışa neden olduğunu bildirmiştir. Yaptığımız çalışmada da kontrol ile \%2.5 Semperfresh ${ }^{\mathrm{TM}}$ uygulanan örneklerin, maya-küf sayım sonuçları arasında istatistiksel açıdan anlamlı bir fark olmadığı tespit edilmiştir $(P>0.05)$. Park ve Zhao (2006) ise yaptıkları çalışmada, $\% 1$ Semperfresh ${ }^{\mathrm{TM}}$ kaplama uygulanmış kiraz örneklerinin $2^{\circ} \mathrm{C}^{\prime} \mathrm{de}$ ve 35 gün depolama süresi boyunca görünür küf yoğunluğunun kontrole göre daha az olduğunu bildirmiştir. Ayrıca görsel olarak incelendiğinde 15. günde aldığımız sonuçlar ile Park ve Zhao (2006)'nun elde ettiği sonuçlar benzerlik göstermektedir.
0. GÜN
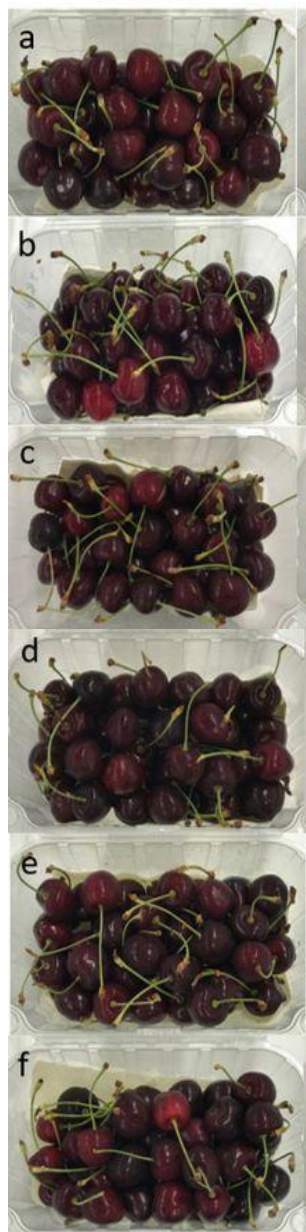

5. GÜN
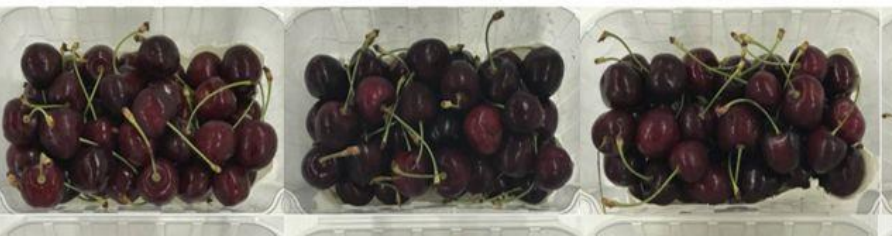

15. GÜN
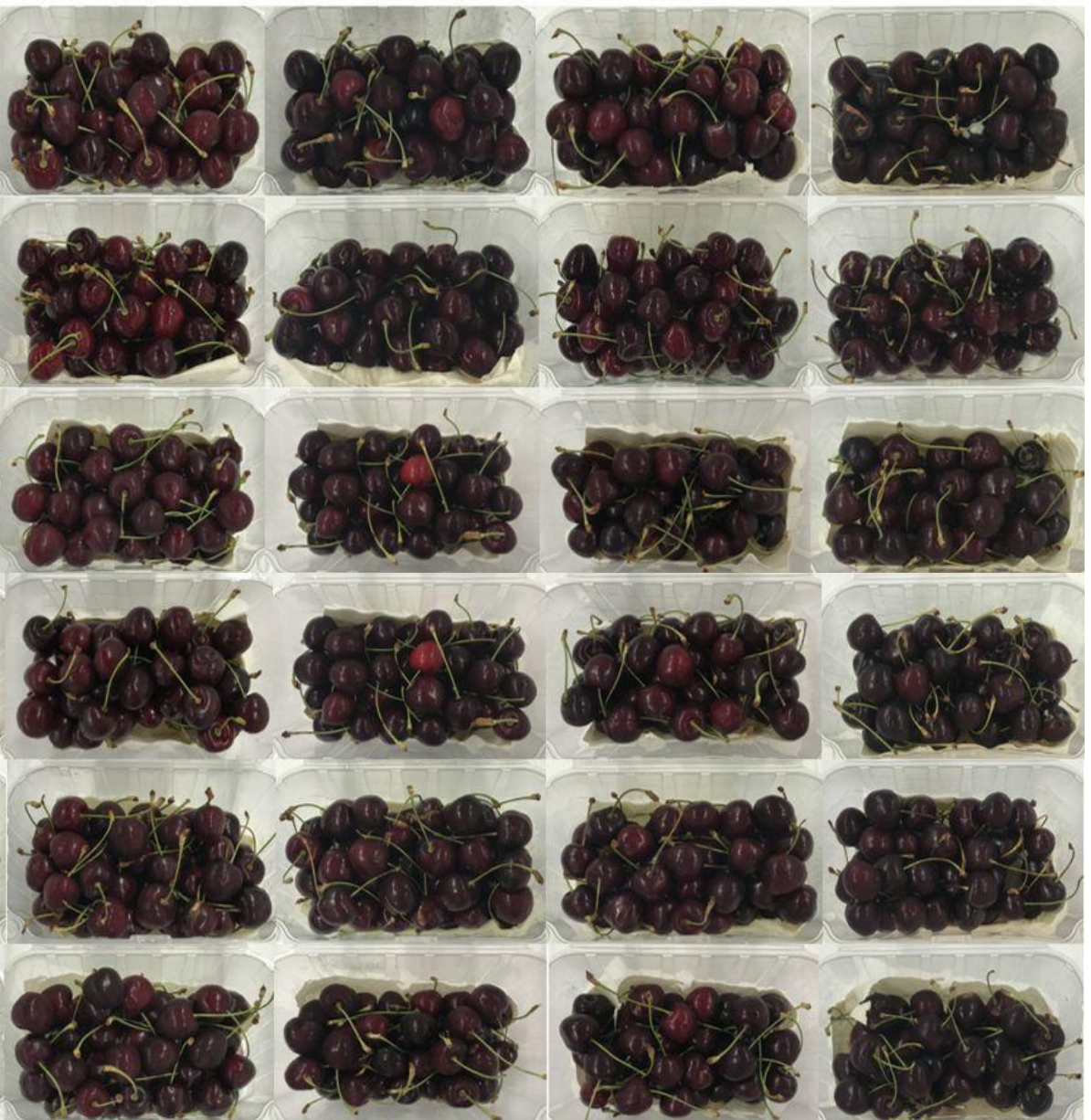

Şekil 1. Depolama boyunca kirazların görüntüsü; a) Kontrol, b) $\% 2.5$ Semperfresh $^{\mathrm{TM}}$, c) $\% 2$ Bioflux, d) $\% 3$ Bioflux, e) $\% 1.5$ Huwa-San, f) \%1 Flavonin ${ }^{\circledR}$ Food

\section{Sonuç}

Sonuç olarak Bioflux, Huwa-San ve Flavonin® ${ }^{\circledR}$ Food 'un mikrobiyal kalite yönünden kiraz meyvesinin yıkama etkinliğini arttırdığ 1 saptanmıştır. Bununla birlikte, yapılan çalışma, sahada özel bir ekipman ve iş gücü gerektirmemesi nedeniyle sektör tarafından belirtilen biyosidal ürünlerin tercih edilebileceğini göstermiştir. Ayrıca Bioflux, Huwa-San ve Flavonin ${ }^{\circledR}$ Food 'un, farklı muhafaza yöntemleri ile birleştirilerek kullanımına yönelik yeni çalışmalar yapılabileceği önerilmektedir.

Kaynaklar 
Abdipour, M., Sadat Malekhossini, P., Hosseinifarahi, M., \& Radi, M. (2020). Integration of UV irradiation and chitosan coating: A powerful treatment for maintaining the postharvest quality of sweet cherry fruit. Scientia Horticulturae, 264, 109197.

Al-Azzazy, M. M., \& Alhewairini, S. S. (2018). Effectiveness of Huwa-San TR50 on tomato russet mite Aculops lycopersici (Massee) (Acari: Eriophyideae). Pakistan Journal of Zoology, 50(3).

Celik, Y., \& SARIALTIN, H. K. (2019). TÜRKIYE'DE KIRAZ ÜRETIMININ YAPISAL ANALİİ. Türk Tartm ve Doğa Bilimleri Dergisi, 596-608.

CNS, (2021). Flavonin®Food. Erişim Adresi: https://www.cnsworld.com/php/flavonin-food_en_75.html

Conte, A., Scrocco, C., Lecce, L., Mastromatteo, M., \& Del Nobile, M. (2009). Ready-to-eat sweet cherries: Study on different packaging systems. Innovative Food Science \& Emerging Technologies, 10(4), 564-571.

Giménez, M. J., Valverde, J. M., Valero, D., Zapata, P. J., Castillo, S., \& Serrano, M. (2016). Postharvest methyl salicylate treatments delay ripening and maintain quality attributes and antioxidant compounds of 'Early lory' sweet cherry. Postharvest Biology and Technology, 117, 102-109.

Ha, J. (2011). Synergistic effects of combined disinfecting treatments using sanitizers and UV to reduce levels of bacillus cereus in oyster mushroom. Journal of the Korean Society for Applied Biological Chemistry, 54(2).

Hayta, E., \& Aday, M. S. (2015). The effect of different electrolyzed water treatments on the quality and sensory attributes of sweet cherry during passive atmosphere packaging storage. Postharvest Biology and Technology, 102, 32-41.

İncekara, H., \& Selek, M. (2020). Görüntü İşleme Yöntemleri Kullanılarak Kiraz Meyvesinin Sinıflandırılması. European Journal of Science and Technology, 108-112.

Kaya, B., \& Demirel Zorba, N. N. (2018). Farklı Su Aktivitesine Sahip Çeşitli Gıdalarda Küf ve Maya Yükünün Belirlenmesi İçin Kullanılan DRBC ve DG18 Besiyerlerinin Etkinliğinin Karşılaştırılması. Ordu Üniversitesi Bilim ve Teknoloji Dergisi, 8(2), 206-214.

Koyuncu, M., Seydim, A., Dilmaçünal, T., Savran, H., \& Taş, T. (2008). Effects of different precooling treatments with ozonated water on the quality of ' 0900 ziraat' sweet cherry fruit. Acta Horticulturae, (795), 831-836.

Marquenie, D., Michiels, C., Geeraerd, A., $\quad$ Schenk, A., Soontjens, C., Van Impe, J., \& Nicolaï, B. (2002). Using survival analysis to investigate the effect of UV-C and heat treatment on storage rot of strawberry and sweet cherry. International Journal of Food Microbiology, 73(2-3), 187-196.

Martínez-Romero, D., Alburquerque, N., Valverde, J., Guillén, F., Castillo, S., Valero, D., \& Serrano, M. (2006). Postharvest sweet cherry quality and safety maintenance by aloe Vera treatment: A new edible coating. Postharvest Biology and Technology, 39(1), 93-100.

Muzaffar, S., Ahmad, M., Wani, S. M., Gani, A., Baba, W. N., Shah, U., ... Wani, T. A. (2016). Ultrasound treatment: Effect on physicochemical, microbial and antioxidant properties of cherry (Prunus avium). Journal of Food Science and Technology, 53(6), 2752-2759.

Nanomik Biotechnology, (2021). Microsome. Erişim Adresi: https://www.nanomik-tech.com/?lang=tr
Onursal, C. E., Çalhan, Ö., Eren, İ., Çetinbaş, M., Butar, S., \& Demirtaş İ. (2013). Derim Öncesi Aminoetoksi-vinilglisin (AVG) Uygulamalarının 0900 Ziraat Kiraz Çeşidinin Soğukta Muhafazası ve Raf Ömrü Kalitesi Üzerine Etkileri. International Journal of Agricultural and Natural Sciences, 6(1), 91-96.

Park, S. I., \& Zhao, Y., (2006). Understanding the Effects of Different Edible Coating Materials on the Storability of 'Bing' Sweet Cherries. Korean Journal of Packaging Science \& Technology, 12(1), 55-61.

Petriccione, M., $\quad$ De $\quad$ Sanctis, F., $\quad$ Pasquariello, M. S., Mastrobuoni, F., $\quad$ Rega, P., $\quad$ Scortichini, M., \& Mencarelli, F. (2014). The effect of Chitosan coating on the quality and nutraceutical traits of sweet cherry during Postharvest life. Food and Bioprocess Technology, 8(2), 394-408.

Serradilla, M. J., Martín, A., Hernandez, A., López-Corrales, M., Lozano, M., \& Córdoba, M. D. (2010). Effect of the commercial ripening stage and Postharvest storage on microbial and aroma changes of 'Ambrunés' sweet cherries. Journal of Agricultural and Food Chemistry, 58(16), 9157-9163.

Serrano, M., Martínez-Romero, D., Castillo, S., Guillén, F., \& Valero, D. (2005). The use of natural antifungal compounds improves the beneficial effect of MAP in sweet cherry storage. Innovative Food Science \& Emerging Technologies, 6(1), 115-123.

Sharma, M., Jacob, J. K., Subramanian, J., \& Paliyath, G. (2010). Hexanal and 1-MCP treatments for enhancing the shelf life and quality of sweet cherry (Prunus avium L.). Scientia Horticulturae, 125(3), 239-247.

Şen, F., Teksür, P. K., \& Türk, B., (2016). Perakende Modifiye Atmosfer Ambalajlarının Kiraz Meyvelerinin Depo ve Raf Ömrüne Etkilerinin Araştırılması. Meyve Bilimi, 1, 100104.

Tokatl1, K., \& Demirdöven, A. (2020). Effects of chitosan edible film coatings on the physicochemical and microbiological qualities of sweet cherry (Prunus avium L.). Scientia Horticulturae, 259, 108656.

Toledo del Árbol, J., Pérez Pulido, R., La Storia, A., Grande Burgos, M. J., Lucas, R., Ercolini, D., \& Gálvez, A. (2016). Microbial diversity in pitted sweet cherries ( prunus avium L.) as affected by high-hydrostatic pressure treatment. Food Research International, 89, 790-796.

Torçuk, A. İ., Bal, E., Gülcü, M., \& Seçkin, G. U. (2016). Etanol Buharı Uygulamasının Kiraz Muhafazası Üzerine Etkilerinin Araştırılması. Meyve Bilimi, 1, 85-93.

TÜİK, (2020). Bitkisel Üretim İstatistikleri. Türkiye İstatistik Kurumu, Ankara.

Türküsay, H., \& Tosun, N. (2005). Hidrojen Peroksit Uygulamalarının Domates Bakteriyel Solgunluk ve Kanser Hastalığı (Clavibacter michiganensis ssp. michiganensis (Smith) Davis et al)'na Etkileri. Ege Üniversitesi Ziraat Fakültesi Dergisi, 42(2), 45-56.

Yaman, Ö., \& Bayoundırl, L. (2002). Effects of an edible coating and cold storage on shelf-life and quality of cherries. $L W T$ - Food Science and Technology, 35(2), 146-150. 